\title{
Intestinal absorption, blood transport and hepatic and muscle metabolism of fatty acids in preruminant and ruminant animals
}

\author{
Jean-François Hocquette*, Dominique Bauchart
}

\author{
Laboratoire croissance et métabolismes des herbivores, Inra, \\ centre de recherches de Clermont-Ferrand/Theix, 63122 Saint-Genès-Champanelle, France
}

(Received 1 July 1998; accepted 6 December 1998)

\begin{abstract}
Current research on lipid metabolism in ruminants aims to improve the growth and health of the animals and the muscle characteristics associated with meat quality. This review, therefore, focuses on fatty acid (FA) metabolism from absorption to partitioning between tissues and metabolic pathways. In young calves, which were given high-fat milk diets, lipid absorption is delayed because the coagulation of milk caseins results in the retention of dietary fat as an insoluble clot in the abomasum. After weaning, the calves were fed forage- and cereal-based diets containing low levels of long-chain fatty acids (LCFA) but leading to high levels of volatile fatty acid (VFA) production by the rumen microflora. Such differences in dietary FA affect: i) the lipid transport system via the production of lipoproteins by the intestine and the liver; and (ii) the subsequent metabolism of lipids and FA by tissues. In preruminant calves, high-fat feed stimulates the secretion of triacylglycerols (TG)-rich lipoproteins (chylomicrons, very-low density lipoproteins (VLDL)). Diets rich in polyunsaturated FA (PUFA) stimulate the production of chylomicrons by the intestine (at peak lipid absorption) and of high density lipoproteins by the liver, leading to high blood concentrations of cholesterol. High levels of non-esterified FA (NEFA) uptake by the liver in high-yielding dairy cows in early lactation leads to TG infiltration of the hepatocytes (fatty liver). This is due to the low chronic capacity of the liver to synthesise and secrete VLDL particles. This abnormality in hepatic FA metabolism involves defects in apolipoprotein B synthesis and low availability of apolipoproteins and lipids for VLDL packaging. Fatty liver in calves is also caused by milk diets containing either soybean oil (rich in $n$-6 PUFA), or coconut oil (rich in C12:0 and C14:0). The ability of muscle tissue to use FA as an energy source depends on its mitochondrial content and, hence, on many physiological factors. The uptake and partitioning of LCFA between oxidation and storage in muscle is regulated by the activity of key intracellular enzymes and binding proteins. One such protein, carnitine palmitoyltransferase I (CPT I) controls the transport of LCFA into mitochondria. Metabolites derived from LCFA inhibit glucose oxidation, decrease the activity of CPT I and decrease the efficiency of ATP production by mitochondria. Most research on tissue lipid metabolism in ruminants is focused on: i) the partitioning of FA oxidation between intracellular peroxisomes and mitochondria in the liver and in muscles; (ii) the regulation of lipid metabolism by leptin, a recently discovered hormone
\end{abstract}

* Correspondence and reprints

E-mail: hocquet@clermont.inra.fr 
secreted by mature adipocytes; and iii) the effects of activation of the nuclear receptors (PPARs and RXR) by LCFA or by phytol metabolites derived from chlorophyll. (C Inra/Elsevier, Paris.

\title{
lipid nutrition / metabolism / fatty acid / liver / muscles / ruminant / preruminant
}

\begin{abstract}
Résumé - Absorption intestinale, transport sanguin et métabolisme hépatique et musculaire des acides gras chez les animaux préruminants et ruminants. Les recherches en cours sur le métabolisme lipidique chez le ruminant visent à améliorer la croissance et la santé des animaux ainsi que les caractéristiques des muscles en relation avec la qualité des viandes. Cette revue a donc pour objectif de traiter spécifiquement le métabolisme des acides gras, de leur absorption intestinale à leur répartition entre tissus ainsi que les voies métaboliques mises en jeu dans ces processus. Chez le Veau préruminant recevant des aliments d'allaitement riches en matières grasses, l'absorption intestinale des lipides est retardée par la coagulation des caséines du lait entraînant la rétention des lipides alimentaires dans un caillot insoluble dans la caillette. Après le sevrage, les veaux reçoivent des aliments solides à base de foin et de céréales pauvres en acides gras à chaîne longue (AGCL) mais conduisant à la formation d'acides gras volatils (AGV) par l'action de la microflore ruminale. De telles différences de composition des acides gras alimentaires entraînent des modifications (i) du système de transport sanguin des lipides via la production de lipoprotéines par l'intestin et le foie et (ii) du métabolisme résultant des lipides et des acides gras par les tissus. Chez le veau préruminant, les aliments lactés riches en matières grasses stimulent la sécrétion des lipoprotéines riches en triglycérides (TG) (chylomicrons, lipoprotéines de très faible densité [VLDL]). Les aliments lactés riches en acides gras polyinsaturés (AGPI) stimulent la production intestinale des chylomicrons (au pic d'absorption des lipides) et des lipoprotéines de haute densité (HDL) par le foie conduisant à élever très fortement la cholestérolémie. Chez la vache laitière haute productrice en début de lactation, le captage de fortes quantités d'acides gras non estérifiés (AGNE) par le foie entraîne une infiltration lipidique du foie (foie gras). Ceci est le résultat d'une faible capacité chronique du foie à synthétiser et sécréter des particules de VLDL. Cette anomalie du métabolisme hépatique des acides gras est consécutive à des défauts de synthèse de l'apolipoprotéine $B$ et d'une faible disponibilité des apolipoprotéines et des lipides pour l'assemblage des VLDL. L'apparition d'un foie gras, également observé chez le veau préruminant, peut être provoquée par la consommation d'aliments d'allaitement enrichis en huile de soja (riche en AGPI n-6) ou en huile de coprah (riche en C12:0 et C14:0). La capacité du tissu musculaire à utiliser les acides gras comme source énergétique dépend de sa teneur en mitochondries et par conséquent de nombreux facteurs physiologiques. Le captage et le partage des AGCL entre les voies d'oxydation et de stockage dans le muscle sont sous le contrôle des activités d'enzymes-clés et de protéines de liaison intracellulaires. Ainsi, la carnitine palmitoyltransférase I (CPT I) contrôle l'entrée des AGCL dans les mitochondries. De plus, les métabolites des AGCL inhibent l'oxydation du glucose, l'activité de la CPT I et l'efficacité de production d'ATP par les mitochondries. La plupart des recherches actuelles sur le métabolisme des lipides chez les ruminants concernent (i) l'équilibre de l'oxydation des acides gras entre les peroxysomes et les mitochondries intracellulaires dans le foie et les muscles, (ii) la régulation du métabolisme lipidique par la leptine, hormone récemment découverte produite par les adipocytes mâtures et (iii) les effets de l'activation de récepteurs nucléaires (PPARs et RXR) par les AGCL et par les métabolites du phytol dérivés de la chlorophylle. (C) Inra/Elsevier, Paris.
\end{abstract}

nutrition lipidique / métabolisme / acides gras / foie / muscles / ruminant / préruminant

Abbreviations: DM, dry matter; FA, fatty acids; FFA, free FA; NEFA, non-esterified FA; VFA, volatile FA; MCFA, medium-chain FA; LCFA, long-chain FA; PUFA, polyunsaturated FA; $\mathrm{KB}$, ketone bodies; $\beta$-OHC $\mathrm{OH}_{4}, \beta$-hydroxybutyrate; TG, triacylglycerols; VLDL, very-low density lipoproteins; LDL, low density lipoproteins; HDL, high density lipoproteins; LPL, lipoprotein lipase; HSL, hormone-sensitive lipase; CS, citrate synthase; $\mathrm{ICDH}$, isocitrate dehydrogenase; $\mathrm{BDH}, \beta$ hydroxybutyrate dehydrogenase; $\mathrm{PDH}$, pyruvate dehydrogenase; FABP, fatty acid binding protein; ACBP, acyl-CoA binding protein; CPT, carnitine palmitoyltransferase; ANT, adenine nucleotide translocase; MTP, microsomal transfer protein; apo B, apolipoprotein B. 


\section{INTRODUCTION}

Preruminant calves are fed whole milk or milk-replacers containing large amounts of lipids as triacylglycerols (TG) $(220-280 \mathrm{~g} / \mathrm{kg}$ diet dry matter (DM)). Therefore, a mean of $30-45 \%$ of energy is absorbed from longchain fatty acids (LCFA) in the calf. Generally, animal fats such as beef tallow or lard are added to the milk-replacers because they contain similar amounts of unsaturated and saturated LCFA to normal milk fat. However, the use of animal food products is, nowadays, associated with the development of bovine spongiform encephalopathy. Vegetable oils containing LCFA, medium-chain fatty acids (MCFA) or polyunsaturated fatty acids (PUFA) have been suggested as an alternative source of FA for milk replacers for calves.

Only small quantities of fats (less than $50 \mathrm{~g} / \mathrm{kg} \mathrm{DM}$ ) are generally present in feed for ruminants after weaning. Therefore, the percentage of energy absorbed as volatile fatty acids (VFA) produced by ruminal fermentation of food averages $50 \%$ for maizebased concentrate diets and $66 \%$ for forage diets, whereas LCFA account for only 8 to $10 \%$ of absorbed energy [53]. Differences in the amount and proportion of VFA finally absorbed may greatly affect energy metabolism and, thereby, the quality of meat or of milk.

Fats can be added to the diets of growing weaned cattle [20] or lactating cows [81] for nutritional or economical reasons to: i) increase the energy content of the diet, thereby satisfying the energy requirements of high-yielding animals; ii) use high-quality cheap fats from industry to replace carbohydrates; iii) manipulate the nutritional value or quality of milk and meat; and iv) improve the metabolic efficiency of key organs (e.g. the liver) and thus, the general health status of the animal.

Consequently, the main aim of current research on lipid metabolism in ruminants is to improve knowledge of the partitioning of the various classes of fatty acids (FA) [VFA, MCFA, LCFA and ketone bodies (KB)] between the major body tissues. A second aim is to investigate the metabolic uses of various FA as energy sources for meat production or as lipogenic precursors for milk fat. This review describes the process of intestinal absorption, transport and fate of FA in the liver and peripheral tissues (mainly muscles). The transport of FA by phospholipids and cholesterol esters will not be considered in this review.

\section{LIPID ABSORPTION AND TRANSPORT TO THE LIVER AND PERIPHERAL TISSUES}

\subsection{Digestion of lipids in preruminants and ruminants}

Weaned ruminants differ from singlestomached animals in that food is fermented by the micro-organisms present in the rumen. Dietary carbohydrates (e.g. cellulose, hemicellulose, starch, soluble sugars) are indeed degraded to hexoses and pentoses which are then fermented to produce VFA, principally acetate, propionate and butyrate (for reviews see $[35,114]$ ). This process results in low levels of intestinal absorption of carbohydrates in ruminants. Therefore, there is much less diet-induced secretion of insulin with a conventional ruminant diet than with a diet rich in lactose which is not fermented in the rumen [44]. Consequently, the liver and peripheral tissues are regularly exposed to large increases in plasma insulin concentration in response to food intake in milk-fed calves and lambs but not in weaned ruminants. This is of great importance because insulin regulates lipid metabolism. One of its major effects is to reduce the delivery of FA to the liver or muscles via its anti-lipolytic effect on adipose tissue.

In ruminants, TG are first extensively hydrolysed in the rumen by lipases, leading to the formation of free FA (FFA) which 
are subjected to partial (C18:2n-6, C18:3n-3) hydrogenation by rumen hydrogenases. Incomplete hydrogenation produces various cis and trans isomers of monoenoic FFA (e.g. C18:1n-9 and C18:1n-7) and isomers of PUFA, such as conjugated linoleic acid. This microbial activity in the rumen results in absorbed FFA being far more saturated than dietary FFA. Absorbed FFA also contain specific bacterial FA, such as odd-chain or branched-chain FA. High-fat diets in ruminants often decrease the extent of carbohydrate digestion, and increase propionic acid levels in the rumen (for reviews, see $[20,23])$. Various techniques of lipid protection (lipid encapsulation, saponification of LCFA) have been used to limit the extent of ruminal lipid hydrogenation and disturbances in fermentation (for reviews, see [5, 23, 54]).

The digestion of fats in preruminants differs from that of adult ruminants because the rumen is not functional. The coagulation of milk caseins also results in the retention of dietary TG as an insoluble clot in the abomasum for several hours. Consequently, peak lipid absorption occurs $5-7 \mathrm{~h}$ later in calves than in conventional monogastrics (for review, see [8]). However, if calves are fed with milk replacers rich in fish protein, which do not curdle in the abomasum, then nutrient absorption is more rapid [112] and the postprandial levels of insulin secretion are often lower [40].

\subsection{Intestinal absorption of lipids in ruminants}

VFA (C2 to C6) are absorbed by the rumen [80] and, to a lesser extent, by the abomasum [32]. VFA are absorbed via the rumen wall by simple diffusion. Most of the acetate, and especially of the butyrate present may be converted into $\mathrm{KB}$ [acetoacetate and $\beta$-hydroxybutyrate $\left.\left(\beta-\mathrm{OHC}_{4}\right)\right]$ during absorption. Thus, the gut is the principal source of VFA and $\mathrm{KB}$ in fed ruminants (figure 1), whereas in monogastrics and preruminants these metabolites are mainly produced by the liver.

For all mammals, medium-chain FA (MCFA, < C12) are absorbed by the small intestine and are mainly secreted as NEFA, specifically in the portal blood (for review see [2]). LCFA are absorbed by the epithelial cells of the small intestine and are reesterified (for review see [5]). The result-

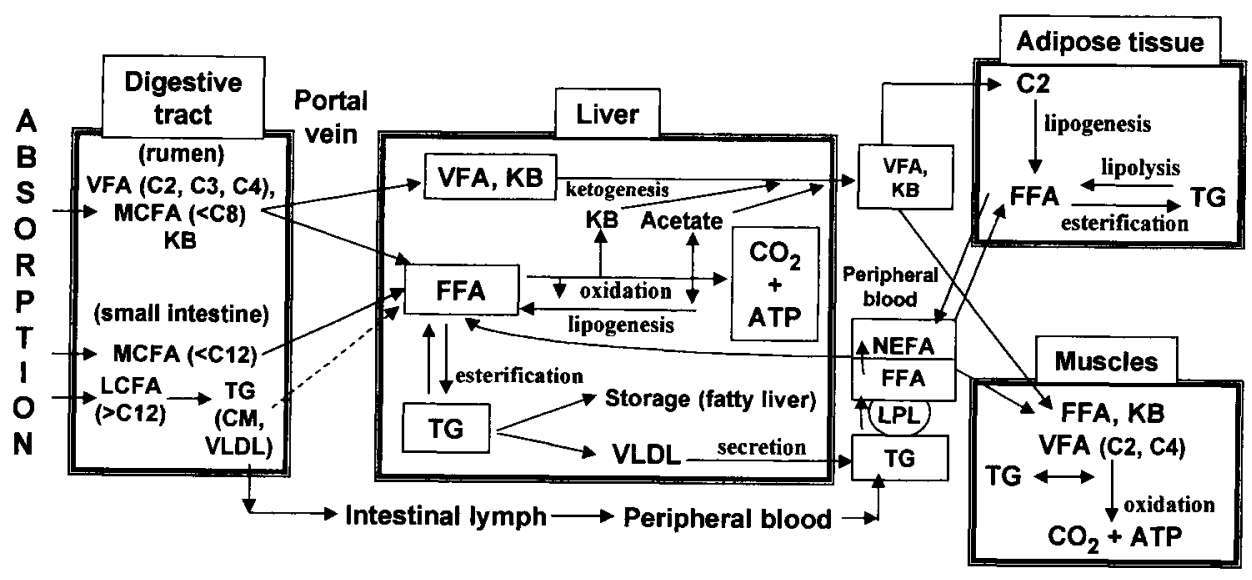

Figure 1. Origin and fate of volatile fatty acids (VFA), ketone bodies (KB), medium-chain fatty acids (MCFA), long-chain fatty acids (LCFA) and triacylglycerols (TG). NEFA, non-esterified fatty acids; FFA, free fatty acids; $\mathrm{C} 2$, acetate; $\mathrm{C}$, propionate; $\mathrm{C} 4$, butyrate; $\mathrm{CM}$, chylomicrons; VLDL, verylow density lipoproteins; LPL, lipoprotein lipase. 
ing TG are incorported into chylomicrons and very-low density lipoproteins (VLDL), which are mostly transported in lymph [61], but also via the portal vein at peak lipid absorption [27] (figure I). In sheep, unsaturated LCFA absorbed by the intestine stimulate the intestinal secretion of chylomicrons, whereas saturated LCFA, which are generated by the hydrogenation of unsaturated FA by ruminal bacteria, specifically cause the intestinal production of VLDL [47].

Total intestinal chylomicron and VLDL production reaches a maximum $8 \mathrm{~h}$ after intake in preruminant calves fed a conventional milk-replacer in a single daily meal [27]. In contrast, with a milk diet that does not curdle in the abomasum, postprandial levels of circulating TG and FFA are higher than in conventionally fed calves $[6,40]$. Chylomicron synthesis and secretion by the gut are stimulated by various dietary factors, including high levels of fat in milk diets, large amounts of amino acids limiting protein synthesis (L-methionine), or the addition of cholesterol to the milk-replacer (for review see [9]).

\subsection{Lipid transport systems}

\subsubsection{VFA and $K B$}

VFA and KB are water-soluble molecules that diffuse more readily than FFA and TG. The plasma concentrations of VFA and KB are much higher in ruminants than in monogastrics such as humans (for review see [82]) or rats (for review see [3]) because large amounts of VFA and $\mathrm{KB}$ are produced by the rumen microflora. The principal circulating $\mathrm{KB}$ in ruminants is $\beta-\mathrm{OHC}_{4}$ but in rats, it is acetoacetate (for review see [3]). Plasma levels of KB may increase in all species during fasting or if there is a high productive demand such as lactation. Nonproductive dairy cows are more resistant than rats to food deprivation because their plasma concentrations of $\mathrm{KB}$ increase to a lesser extent than those in fasted rats. In contrast, plasma concentrations of $\mathrm{KB}$ increase more during lactation in cows than in rats (for review see [3]). In normally fed sheep, about $70 \%$ of the KB originate from the gut and $30 \%$ from the liver. $\mathrm{KB}$ are taken up mainly by muscles $(60 \%)$ and, to a lesser extent, by the liver $(20 \%)$ and the kidney $(20 \%)$. However, the relative size of these fluxes change greatly during fasting, pregnancy or lactation (for review [48]).

\subsection{2. $L C F A$ and TG}

In the fed animal, NEFA account for less than $5 \%$ of the total mass of plasma lipids. TG ( $<10 \%$ of total plasma lipids) is present mainly in the lightest lipoproteins (chylomicrons, VLDL). Pethick and Dunshea [84] quantified NEFA and TG fluxes over a 24-h period in sheep fed maintenance roughage diets. They found that $40 \%$ of NEFA originate from fat mobilisation in adipose tissues and $60 \%$ originate from the hydrolysis of circulating TG by lipoprotein lipase (LPL). This suggests a key role for LPL in the regulation of overall lipid metabolism. TG are produced in the gut (65\% of total circulating TG) or the liver (35\% of TG according to Pethick and Dunshea [84]). These fluxes, however, depend on the species, the type of diet and the kinetics of nutrient absorption after a meal. Nevertheless, most of the TG of dairy cows also have an intestinal rather than hepatic origin (for review, see [43]).

The composition and characteristics of the bovine lipoproteins have been investigated by several analytical methods in various physiological and nutritional conditions (for review see [5]). Most of the lipoproteins in bovine plasma are high density lipoproteins (HDL) (> $80 \%$ of total lipoproteins) whereas, in human plasma, low density lipoproteins (LDL) are the most abundant ( $>55 \%$ of total lipoproteins). However, as in humans, the principal bovine lipoproteins of intestinal origin in the lymph are chylomicrons and VLDL, which con- 
tain a unique isoform of apolipoprotein B (apo B) which is similar to human apo B48 [62]. In contrast, plasma VLDL contain two apo B isoforms: apo B 48 and apo B 100 , both derived from the same gene. The truncated isoform, apo B 48, is generated by editing, a post-transcriptional RNA modification. Apo B mRNA is almost completely edited in the bovine intestine $(95 \%)$ with less editing in sheep (40\%) and horses (73\%) [39]. This is why the VLDL present in the intestinal lymph of cattle contain only apo B48. Apo B mRNA is detectable at early stage of gestation ( 90 days) in bovine foetal liver [42].

\subsection{Fate of lipids}

Absorbed acetate and butyrate are used primarily as energy sources. They are oxidised via the citric acid cycle which takes place in the mitochondria. Acetate is also the principal substrate for lipogenesis in all fat deposits except those of intramuscular fatty tissue [104]. Propionate is used mostly for gluconeogenesis within the liver and is thus, the principal source of glucose in weaned ruminants (figure 2).

NEFA are stored as TG within the liver or adipose tissues, oxidised in tissues such as the liver, heart or muscles or are recycled by the liver (figure 1). The liver secretes lipids in various forms including acetate, $\mathrm{KB}$ and lipoproteins containing TG. Pethick and Dunshea [84] estimated that, in sheep fed maintenance roughage diets, $34 \%$ of circulating NEFA are stored, $40 \%$ oxidised and $26 \%$ recycled by the liver over a $24-\mathrm{h}$ period.

The rate of VLDL synthesis and secretion by the liver is much smaller in cattle than in primates or in rodents [93]. This may be the reason why bovine livers, especially those of calves fed high-fat diets or of pregnant or lactating cows, do not efficiently recycle FFA if large amounts of FA are taken up. The animals in such cases develop steatosis. Therefore, a better understanding of hepatic lipid metabolism is required if we are to understand how to manipulate biological mechanisms to restore the health or high yields of milk or meat of these animals (for reviews, see [8, 41]).

\section{FATTY ACID METABOLISM IN THE LIVER}

\subsection{Origin and metabolism of short-chain fatty acids in the liver}

Short-chain FA (VFA and KB) originate either in the gut, from which they are transported by the portal vein, or in hepatocytes from LCFA catabolism. Short-chain FA are then catabolysed, recycled to produce other metabolites or re-secreted into the general circulation (figure 2).

As $85-90 \%$ of the propionate in the portal vein is removed in a single pass through the liver, only small amounts of propionate reach other tissues. Most propionate is converted to glucose within the liver so, the rate of gluconeogenesis increases with food intake in ruminants, in contrast to the situation observed in monogastric animals. Propionate inhibits the use of other gluconeogenic substrates, such as lactate (for review, see [15]). It inhibits short-chain FA oxidation [101] and ketogenesis. Several mechanisms for such inhibition have ben suggested (for review, see [43]). Propionate also inhibits de novo lipogenesis (incorporation of acetate into FA) in rat liver [79].

More than $80 \%$ of the absorbed butyrate is removed in a single pass through the liver. The end-products of butyrate metabolism by the liver are acetyl-CoA, LCFA and KB. However, more KB are produced by the liver if LCFA is available as a substrate than if butyrate is used (for reviews, see [15, 114]).

Acetate is not metabolised by the liver to any great extent because only a small proportion of the available acetate is taken up by the liver, ensuring a large supply of 


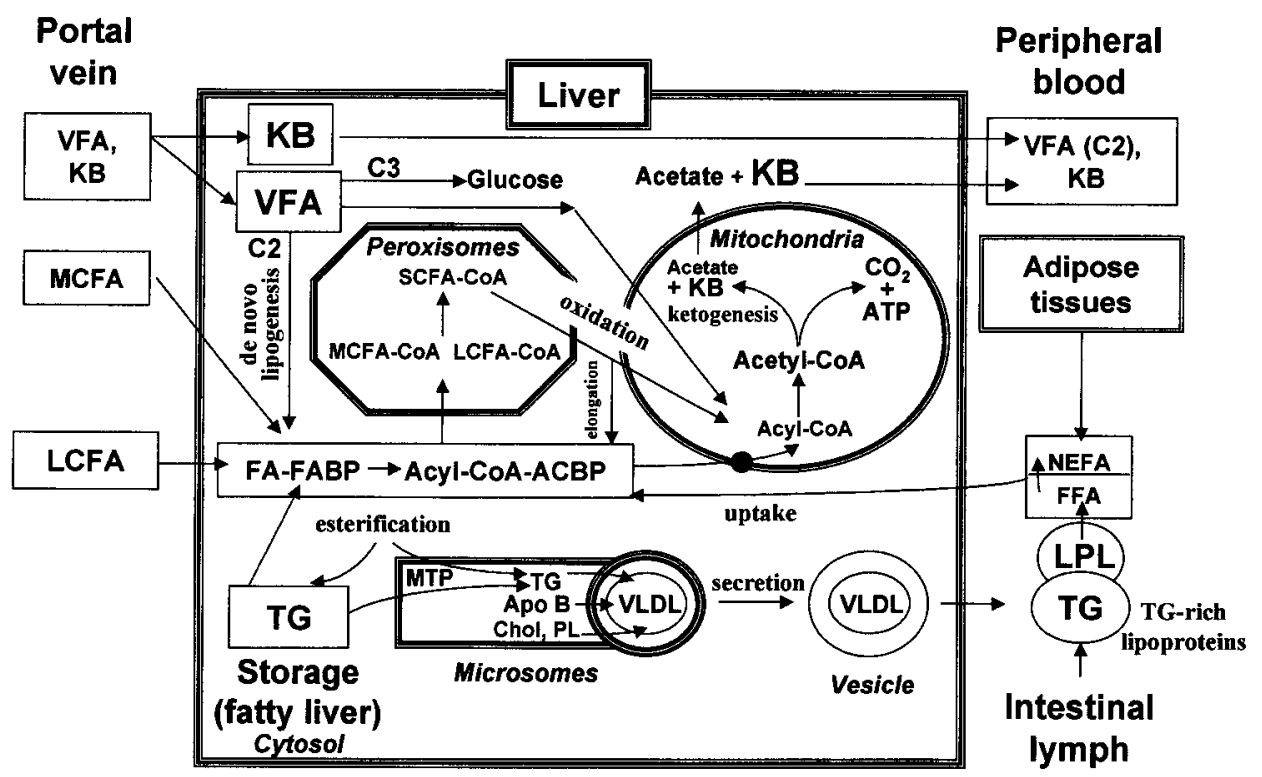

Figure 2. Hepatic metabolism of volatile fatty acids (VFA), ketone bodies (KB), medium-chain fatty acids (MCFA), long-chain fatty acids (LCFA) and triacylglycerols (TG). FA, fatty acids; FFA, free FA; NEFA, non-esterified FA; SCFA, short-chain FA; C2, acetate; C3, propionate; Chol, cholesterol; PL, phospholipides; VLDL, very-low density lipoproteins; LPL, lipoprotein lipase; FABP, fatty acid binding protein; acyl-CoA, acyl-CoA binding protein; MTP, microsomal transfer protein. The black circle represents the carnitine-dependent system of FA transport across mitochondrial membranes.

acetate for other tissues. However, the uptake of acetate is masked by coincident acetate production by the liver. Within the liver, acetate is mainly used for anabolism, such as de novo LCFA lipogenesis rather than for oxidation and ATP production (for review see [114]).

The different fates of VFA are probably due to the difference in the ability of the bovine liver to activate VFA: the bovine liver contains acyl-CoA synthetases necessary for the uptake of propionate and butyrate but has little acetyl-CoA synthetase activity [95].

\subsection{Origin and metabolism of LCFA in the liver}

The pool of LCFA in the liver is derived mainly from plasma NEFA (figure 2). The liver removes $7-25 \%$ of the NEFA presented to it. The supply of NEFA to the liver depends on blood flow and NEFA concentration, which increases with fat mobilisation from adipose tissue $[16,28]$. Finally, the hydrolysis of circulating TG by a lipase may also be a minor source of hepatic LCFA (for reviews see $[8,10,31])$. There is almost no hepatic lipase activity in cattle, in contrast to the situation in rodents, so, the lipase involved is probably the LPL bound to the endothelium of capillaries in the hepatic sinusoids (for reviews, see $[8,16]$ ).

The LCFA in the liver is esterified or oxidised (figure 2). The partitioning between these two pathways is regulated, at least in part, by two binding proteins: the FA binding protein (FABP) and the acyl-CoA binding protein (ACBP). The function of these proteins may be to create two cytoplasmic 
pools of unactivated and activated FA which are then directed to the sites of esterification or oxidation within hepatocytes. The bovine ACBP has been purified from cow liver and sequenced [74]. In rodents, the expression of the liver-type FABP is transcriptionally increased by LCFA but not by SCFA [73]. This mechanism may be of great importance in preruminant calves fed fatrich diets.

The various metabolic pathways involved in LCFA metabolism will be discussed in greater details later. Briefly, esterification produces $\mathrm{TG}$, which are either stored in the cytosol or transported into the microsomes and secreted in VLDL particles (for review see [41]). Alternatively, FA may be oxidised in peroxisomes and mitochondria, to produce free energy (figure 2). Acyl-CoA is transported into or out of the various liver organelles (microsomes, peroxisomes, mitochondria) via a carnitine-dependent system involving carnitine palmitoyl- and carnitine octanoyltransferases (CPTs and COTs, respectively). These enzymes are products of separate genes and the regulation of their activity, especially by malonyl-CoA, is of key importance for overall hepatic lipid metabolism (for review, see [13]).

The nature of the diet (fat to carbohydrate ratio, fat content, FA composition) and hormones regulate the partitioning of fats between the various hepatic metabolic pathways. For example, insulin stimulates de novo lipogenesis and FA esterification [17] but inhibits FA oxidation (for review, see [122]). In cows, $76 \%$ of palmitate is esterified and $24 \%$ oxidised by liver slices in the fed state, whereas $33 \%$ is esterified and $66 \%$ oxidised in the fasted state [25].

Dysregulation of the partitioning of FA between these hepatic metabolic routes may lead to accumulation of TG in the liver (fatty liver) or ketosis. Fatty liver occurs in $20-60 \%$ of dairy cows at calving. It results in poor liver function, low voluntary feed intake, low disease resistance and slow recovery from disease. Its incidence may be reduced by nutritional treatments such as the intravenous infusion of L-methionine and L-lysine or choline, which stimulate hepatic VLDL secretion, thereby decreasing hepatic TG storage. Fatty liver resolves if the FA supply to the liver is reduced, for example after 12 weeks of lactation, when FA mobilisation from the adipose tissue is not so high (for reviews, see $[16,28,41,43])$. Ketosis and FA oxidation in general are the major means of removing excess fat from the liver. KB may inhibit adipose tissue lipolysis, thereby reducing the FA supply to the liver and preventing hepatic FA accumulation (for review, see [31]). Fatty liver may also occur in veal calves, it may affect the growth and health of these animals (for review, see [9]) and their liver metabolism and function [16, 17, 110]. Lipid infiltration in the veal calf can be resolved with low-fat diets or prevented by the addition of sorbitol to the milk-replacers [7].

\subsection{Regulation of LCFA transport into mitochondria}

LCFA-CoA esters are transported into mitochondria via a complex carnitine-dependent process which involves the co-ordinated action of two carnitine palmitoyltransferases (CPT I and CPT II) and of a translocase (for reviews, see [13, 70]). Carnitine levels in the ruminant liver increase in various conditions of metabolic stress (fasting, diabetes, toxaemia during pregnancy, hepatic TG accumulation) [106]. Carnitine stimulates palmitate oxidation in bovine liver slices $[24,25,55]$ suggesting that it regulates FA flux via the oxidative pathway. However, it is generally accepted that CPT I activity is the rate-limiting step of LCFA translocation into mitochondria, which regulates LCFA oxidation, and thereby, ketogenesis. CPT I activity is inhibited by malonyl-CoA, the synthesis from acetate of which is stimulated by insulin. Malonyl-CoA [24, 55], acetate and insulin [56] have been shown to inhibit palmitate 
oxidation in bovine liver slices. The bovine hepatic CPT I is 8 to 10 times more sensitive to malonyl-CoA inhibition [55] than is that of the rat [71]. If insulin levels are high, the effects of the changes in absolute malonylCoA concentration may be amplified by concomitant changes in CPT I kinetic properties or by a decrease in CPT I gene expression (for review, see [122]). In contrast, low insulin levels in early lactation are likely to result in low malonyl-CoA concentration, thereby increasing ketosis. CPT I may also be inhibited by methylmalonyl-CoA produced from propionate. If the amounts of propionate reaching the liver are low, due, for example, to low food intake, then the level of ketosis in the ruminant liver may be high (for review, see [121]). Other studies have shown that incubation of cultured rabbit foetal hepatocytes with LCFA induces expression of the gene encoding CPT I [92].
If such a mechanism operates in vivo in cattle, there should be very large changes in CPT I gene expression on weaning of the calf. However, VFA, KB and MCFA, readily penetrate into liver mitochondria independently of carnitine and of CPT I.

\subsection{Regulation of LCFA catabolism and ketogenesis}

FA are broken down by the $\beta$-oxidation pathway in mitochondria to give acetyl-CoA (figure 3) which is completely broken down via the Krebs cycle, or converted into acetate or KB (for review, see [45]). Depending on nutritional status, 4-30\% of circulating acetate and $10-55 \%$ of $\beta-\mathrm{OHC}_{4}$ may be derived from hepatic oxidation of LCFA in cattle (for review, see [31]). Ketogenesis is stimulated by fasting due to increased fat mobilisation, and to a low insulin/glucagon

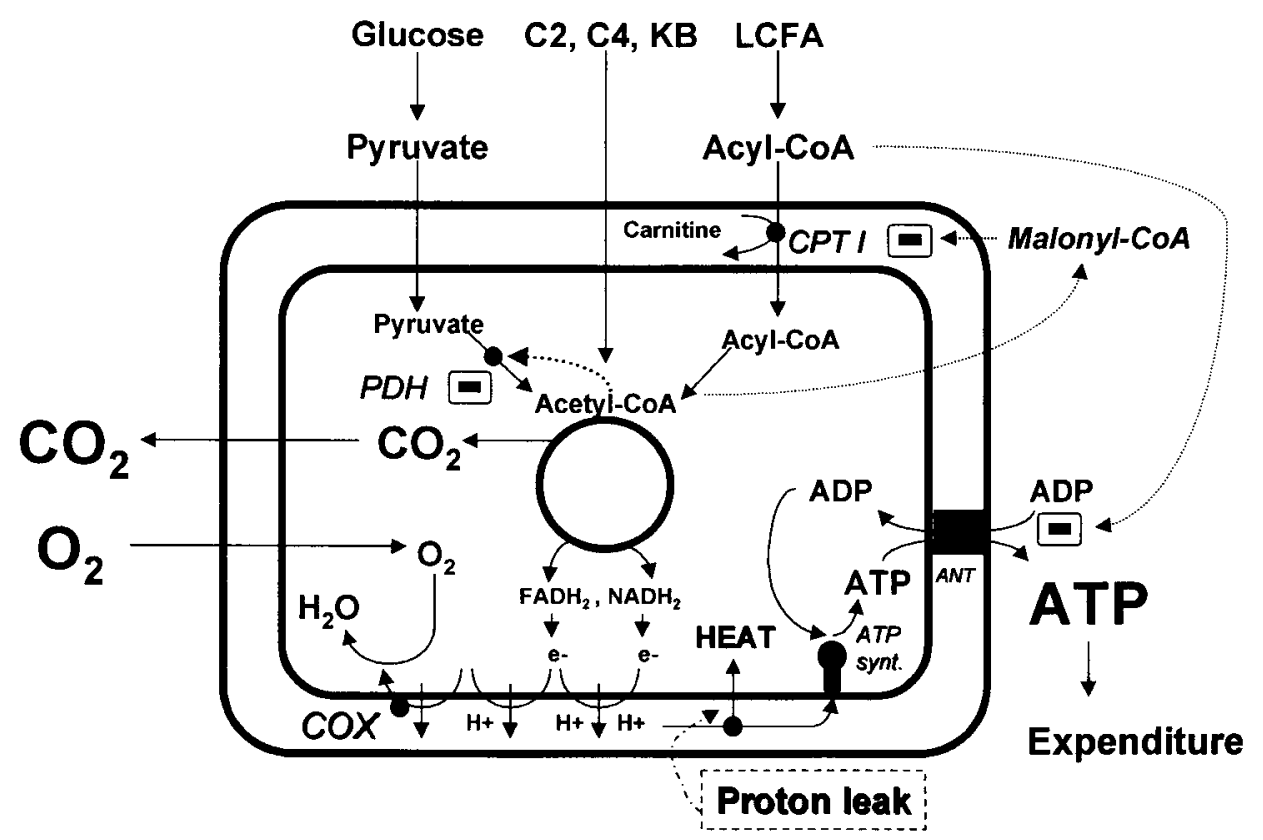

Figure 3. Overview of the metabolic pathways in mitochondria. ANT: adenine nucleotide translocase; ATP Synt.: ATP synthase; KB, ketone bodies; LCFA, long-chain fatty acids; $\mathrm{C} 2$, acetate; $\mathrm{C} 4$, butyrate; PDH, pyruvate dehydrogenase; CPT I, carnitine palmitoyltransferase I; COX, cytochrome $c$ oxidase; square with black bar inside, inhibition of enzymes by metabolites (adapted from [51]). 
ratio stimulating FA transfer into mitochondria. Pregnancy and, particularly, lactation, result in even greater levels of fat mobilisation leading to hyperketonaemia. There are several enzymes for each step in the $\beta$-oxidation pathway, differing in their chain-length specificity [30]. The ruminant liver contains two mitochondrial 3-hydroxyacyl-CoA dehydrogenases whereas the liver of monogastric animals contains only one [58]. Propionyl-CoA inhibits the short-chain acyl-CoA dehydrogenase in bovine liver [101], demonstrating that FA $\beta$-oxidation may be decreased by propionate originating from the rumen. A high NADH/NAD ratio also inhibits the $\beta$-oxidation of $F A$. This ratio is regulated within the cytosol or mitochondria by specific dehydrogenases particularly the $\beta$-hydroxybutyrate dehydrogenase (BDH). However, in ruminants, the BDH activity within hepatic mitochondria is $50-100$ times lower than that in rats and humans [69]. This may be a specific mechanism by which the ruminant liver increases the NADH/NAD ratio, thereby limiting FA oxidation and ketogenesis (for review see [31]). In addition, the conversion of propionate to propionyl-CoA or succinyl-CoA inhibits 3-hydroxy-3-methyl-glutaryl-CoA synthase, thereby decreasing ketogenesis [68] (for review, see [43]).

It is well known from studies in other species that, unlike mitochondria, peroxisomes only shorten FA (figure 2), and that they are especially active against very longchain FA, and unsaturated FA (for reviews, see $[45,113])$. The rate of laurate $\beta$-oxidation in peroxisomes is, however, higher than that of palmitate not only in rats (for review, see [113]) but also in preruminant calves [90]. FA is also transported across peroxisomal membranes via a carnitine-dependent system which is sensitive to malonyl-CoA [13]. A soluble CPT which is probably peroxisomal in origin has been identified in bovine liver homogenates. This enzyme is more active against LCFA than is the hepatic peroxisomal CPT from rat or mouse [94].

\subsection{Free energy production}

The last step is the conversion into ATP of the free energy obtained from FA catabolism (figures 2 and 3). FA catabolism leads to protons accumulating between the two mitochondrial membranes via the respiratory chain. The process is similar in heart, liver and muscles (research with the bovine heart is described here). However, cytochrome $c$ oxidase, which catalyses the principal regulatory step of the respiratory chain, differs in kinetic and structural properties between the liver and the heart in cattle [72]. Various observations suggest that there is species-specific and tissue-specific regulation of the energy supply because the tissue-specific expression of the genes encoding subunits VIa and VIII of cytochrome $c$ oxidase in the heart differs between bovines, rats and humans [1]. The next step is the generation of ATP from the proton gradient by ATP synthase. However, some protons are lost because the inner mitochondrial membrane is leaky; ATP production is therefore relatively inefficient with ATP production uncoupled from nutrient catabolism (figure 3). The level of proton leakage in the liver is similar for all species studied [96] and this process is thought to play a key role in the regulation of hepatic energy metabolism [107].

\subsection{TG synthesis and deposition within the liver}

The rates of de novo lipogenesis and TG secretion by ruminant hepatocytes are lower than those in rats, rabbits and chickens [93]. Therefore, much attention is focused on TG metabolism and VLDL secretion in ruminants to determine the biological mechanisms that could prevent the development of fatty liver (figure 2) [16, 41].

It is clear that the partitioning of FA between oxidation and esterification is critical for LCFA metabolism in the bovine liver. Glucose and propionate are thought to increase LCFA esterification because they 
are converted into glycerol. This may be one of the reasons why they both inhibit palmitate oxidation in bovine liver slices $[55,56]$.

The various steps involved in the formation of TG from LCFA and TG secretion have been reviewed by Gruffat et al. [41]. Three esterification reactions and one hydrolysis reaction are required to bind three molecules of LCFA to one molecule of glycerol-3 phosphate. Studies in sheep, rats (for reviews, see $[8,10,41])$, and more recently, in calves (Gruffat et al., unpublished data) have shown that there are two hepatic TG pools: a large cytoplasmic storage pool, and a small microsomal secretory pool (figure 2). The transport of TG from microsomal membranes to the site of VLDL assembly is catalysed by the microsomal transfer protein (MTP). TG synthesised from circulating LCFA taken up by the liver are thought to be initially transferred into the cytosolic storage pool. If these TG are recruited for VLDL packaging, they are probably hydrolysed to give LCFA before being re-esterified in the microsomes. Secretory TG in VLDL are thought, however, to be mainly derived from FFA synthesised de novo in the liver. The level of de novo lipogenesis in the liver is low in cattle, so the microsomal secretory pool may be of minor importance. This may limit the secretion of VLDL predisposing the animal to fatty liver. Alternatively, the low levels of VLDL secretion in cattle may be due to: i) a slow rate of apo B 100 synthesis and incorporation into VLDL particles; ii) catabolism of newly synthesised hepatic apo B 100; or iii) a low MTP activity (for reviews, see $[8,10,41]$ ).

An important factor regulating hepatic TG metabolism is the nature of the dietary FA, such as PUFA. This may, however, be more important in calves than in weaned animals because: i) the dietary FA supply is much greater before than after weaning; and ii) extensive hydrogenation of dietary LCFA occurs in the rumen. PUFA-rich diets (soybean oil rich in C18:2n-6) lead to hepatic
TG infiltration and the apparent net secretion of VLDL by the liver in calves. The accumulation of TG may result from: i) a higher rate of TG synthesis than of VLDL secretion; ii) a low rate of FA oxidation; or, more likely, iii) high levels of cholesterol ester secretion at the expense of TG secretion. Indeed, PUFA-rich diets stimulate the secretion of HDL by the liver leading to hypercholesterolaemia $[64,65]$.

The overall effect of insulin on hepatic TG secretion is unclear because insulin stimulates esterification and lipogenesis but decreases the availability of apo B for secretion by increasing its rate of degradation. The balance between these effects depends on the experimental conditions (in vivo versus in vitro) and interactions with other regulatory mechanisms such as the variation of cell volume and oxygen supply (for review, see [122]).

Thus, the molecular mechanisms involved in FA esterification and catabolism and also in TG secretion by the bovine liver have been studied especially in the dairy cow and in the calf. However, further work is required to control the partitioning of $\mathrm{FA}$ between oxidation, deposition and secretion as TG in VLDL in order to prevent fatty liver.

\section{FATTY ACID METABOLISM IN CARDIAC AND SKELETAL MUSCLE}

\subsection{Metabolic characteristics of bovine skeletal muscles}

Muscle tissue is composed of fibres and to a lesser extent, of adipocytes and connective tissue. FA are stored as TG in intramuscular adipocytes or muscle fibres, or are broken down within fibre peroxisomes and mitochondria (figure 4). The various muscles of the body consist of several kinds of fibre with different metabolic properties (oxidative, glycolytic, oxido-glycolytic). These fibres are present in various proportions in muscles depending on: i) the loca- 


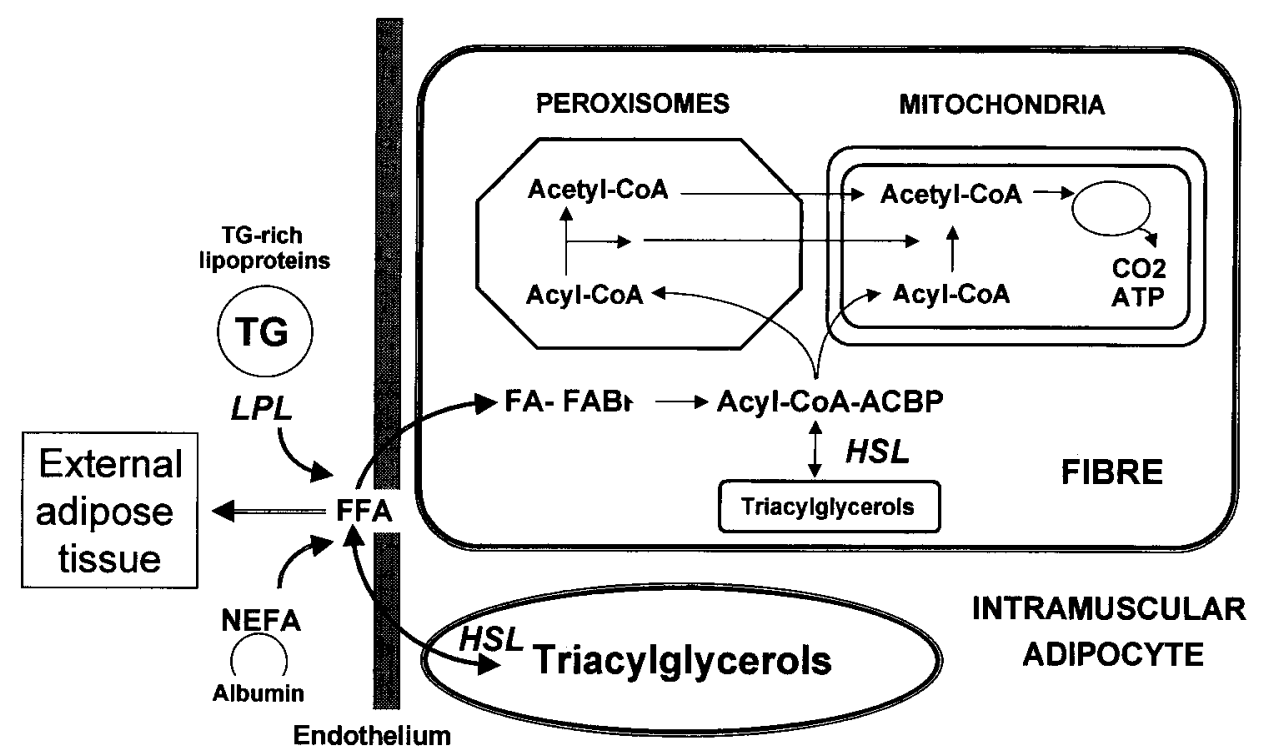

Figure 4. Fate of fat in peripheral tissues and partitioning of fatty acids (FA) within the muscle tissue. LPL, lipoprotein lipase; HSL, hormone-sensitive lipase; FABP, fatty acid binding protein; ACBP, acyl-CoA binding protein; NEFA, non-esterified fatty acids; FFA, free fatty acids (adapted from Veerkamp [115]).

tion of the muscle in the body; ii) the animal species; and iii) other nutritional and physiological characteristics such as exercise training. Therefore, understanding the relative importance of fat in the energy metabolism of muscles requires knowledge of the metabolic type of the muscle studied. The biochemical pathways involved in LCFA, KB and VFA catabolism are qualitatively similar in the heart and skeletal muscles, but FA oxidation rates differ: heart $>$ oxidative skeletal muscle $>$ oxido-glycolytic muscles $>$ glycolytic muscles.

Enzymes involved in carbohydrate or fat catabolism are straightforward to assay and are often used to characterise the metabolic properties of muscles. From these enzyme activities, species can be tentatively ranked according to the mean oxidative capacity of their muscles: horse $\approx$ sheep $>$ cattle $\approx$ rabbit $>$ pig (for review, see [52]). However, the metabolic properties of individual muscles are not uniform. For example, there are differences between the left and right ventricles in bovine heart muscle [22] and between proximal and distal portions of the bovine semitendinosus muscle [14].

Active ruminants foraging widely for food have higher oxidative muscle energy metabolism than sedentary ruminants that always remain within a defined home range [109]. Furthermore, comparisons of cattle, pigs, rabbit and rodents have shown that citrate synthase (CS) activity in the diaphragm is correlated with resting breathing frequency [12]. This shows that the metabolic character of a muscle is consistent with its function.

The oxidative capacity of muscles is directly proportional to their total volume of mitochondria, which is higher in small (e.g. rodents) than in large (e.g. ruminants) animals, higher in active than in sedentary species and higher in red than in white muscles (for review, see [52]). There are two 
populations of mitochondria (intermyofibrillar and subsarcolemmal) in skeletal muscle, which differ in their biochemical properties in many species including cattle [88]. Their functions may be related to specific regional (contractile elements versus cytoplasm) substrate availability or ATP needs (for review, see [52]).

\subsection{Biochemical pathways involved in the metabolism of VFA, $\mathrm{KB}$ and LCFA}

The biochemical pathways involved in FA oxidation and subsequent ATP production by the heart and skeletal muscles are similar for all species $[21,66]$. As in the liver, FA partitioning between storage and catabolism is regulated by hormones. For example, insulin decreases LCFA oxidation, resulting in the incorporation of LCFA into TG. LCFA and activated LCFA (acyl$\mathrm{CoA}$ ) also regulate energy metabolism by acting on rate-limiting enzymes (for review, see [33]).

Net acetate or KB use by muscle is linearly related to arterial acetate concentration, but $\beta-\mathrm{OHC}_{4}$ uptake by muscle is saturated above 3-4 $\mathrm{mM}[83,85]$. Extraction rates by the hind-limb average $35-45 \%$ for acetate and $10-45 \%$ for $\beta-\mathrm{OHC}_{4}$ in ruminants [86]. Most of the acetate and KB used are directly oxidised, resulting in 15-29\% (for acetate) and $18 \%$ (for KB) muscle oxidation in fed sheep at rest [82]. BDH converts $\beta-\mathrm{OHC}_{4}$ into acetoacetate which is then broken down by mitochondria (figure 3 ). $\mathrm{BDH}$ content and activity are much higher in the hearts of sheep and cattle than in the hearts of rats and humans in relationships with a higher rate of $\beta-\mathrm{OHC}_{4}$ use by muscles of ruminants [69].

LPL hydrolyses TG from circulating lipoproteins and thus controls the deliverey of energy from lipoproteins to muscles, even in ruminants [84] (figure 4). Muscle LPL activity and gene expression are, however, lower in ruminants than in rodents [51]. Muscle LPL may play a key role in replenishing intramuscular TG stores depleted during contractile activity. The TG stored in the cytosol of muscle fibres are hydrolysed by a hormone-sensitive lipase (HSL) (figure 4) (for review, see [21]) which has been purified from the bovine heart [103]. This enzyme is identical to the HSL present in adipose tissue. HSL and LPL may function as a co-ordinated unit in meeting the energy demands of the muscle (for review, see [21]).

The uptake of NEFA by muscle is directly dependent on arterial NEFA concentrations up to $1 \mathrm{mM}$. Gross extraction of NEFA by resting muscle averages $20 \%$ in sheep. The level of direct oxidation of NEFA by the resting muscle is low (from 3 to $40 \%$ in sheep or steers). NEFA may be oxidised after passing through intramuscular pools of TG (in adipocytes between muscle fibres or as lipid droplets within muscle fibres) or may be stored as acetylcarnitine in the cytosol of fibres, particularly in ruminant muscles which contain high concentrations of carnitine. NEFA account for $5 \%$ of the energy metabolism in sheep, whereas they account for 70-100\% in humans, due to large differences in the dietary intake of LCFA between these two species (for reviews see [52, 84]). As in the liver, the mechanism of NEFA uptake by the muscle cells is probably controlled by the partitioning of NEFA between binding sites in the blood (albumin), plasma membranes and intracellular FABP [115] or ACBP (figure 4). Overexpression of the bovine ACBP suggests that ACBP creates a pool of acyl-CoA, similarly to the way that FABP creates a pool of LCFA (for review, see [33]). FABP may transfer FA to oxidation (peroxisomes and mitochondria) or esterification sites for free energy production or storage, respectively. A positive correlation has indeed been demonstrated between FABP activity and the rate of palmitate esterification in fibre strips of the longissimus thoracis muscle of cattle [105]. How- 
ever, the marbling score of this muscle is not related to muscle FABP activity because most of the intramuscular TG are stored in intramuscular adipocytes (figure 4) which express another type of FABP [75].

\subsection{Catabolism of FA and the generation of free energy}

FA may be partially degraded in peroxisomes to yield acyl-CoA molecules with shorter chains or they may be directly and completely broken down into $\mathrm{CO}_{2}$ within mitochondria. FA is transported into mitochondria via the CPT system (see description above and figure 3). The carnitine content of muscles is much higher in ruminants than in rats $[49,106]$ or pigs [77]. Carnitine in muscles may act as an acetyl buffer system, acetyl groups coming from circulating acetate or being produced by LCFA catabolism. Nevertheless, the transport of FA into mitochondria is considered to be limited by CPT I activity, which is strongly inhibited by malonyl-CoA, as in the liver. Studies in other species have demonstrated the existence of two CPT I isoenzymes: the liver-type (L-CPT I) and the muscle-type (M-CPT I), both of which are expressed in the heart of newborn rats. These two isoforms differ in their biochemical properties (sensitivity to malonyl-CoA for example) (for review, see [70]).

LCFA, VFA and $\mathrm{KB}$ are converted into acetyl-CoA in mitochondria. The acetyl$\mathrm{CoA}$ is then broken down by enzymes of the Krebs cycle. The enzymes influencing flux through the Krebs cycle are CS, isocitrate dehydrogenase (ICDH) and 2-oxoglutarate dehydrogenase [46]. The liberation of calcium during muscle contraction activates mitochondrial dehydrogenases, thereby stimulating FA oxidation [66]. Only a fraction of the free energy derived from FA catabolism (approximately $40 \%$ ) is converted into ATP due to proton leakage ( $f \mathrm{ig}$ ure 3). ATP synthesis has been studied in bovine heart [108]. The physiological sig- nificance of proton leakage may be: i) a heat production to maintain body temperature; ii) greater potential for the regulation of ATP production in response to higher energy requirements; iii) a reduction in harmful free radical production; and iv) the regulation of carbon flux by keeping the cell NAD/NADH ratio high (for review, see [96]). The transport of ADP into mitochondria and the export of newly synthesised ATP are catalysed by the mitochondrial adenine nucleotide translocase (ANT), this step being generally considered to be the overall ratelimiting step in energy metabolism (for review, see [33]).

The various products of FA catabolism regulate mitochondrial activity (figure 3 ): i) high levels of NADH, ATP and acetyl$\mathrm{CoA}$ inhibit pyruvate dehydrogenase (PDH) activity (for review, see [46]) resulting in low levels of oxidative catabolism of the pyruvate derived from glucose. Bovine heart PDH activity is also inhibited by $100 \mu \mathrm{M}$ palmitoyl-CoA [60]. This interaction between carbohydrates and FA is known as the Randle Cycle; ii) malonyl-CoA inhibits FA transport into the mitochondria; iii) the incomplete coupling of nutrient oxidation with oxidative phosphorylation in mitochondria may be rendered even less complete by LCFA [98]. Indeed, acyl-CoA esters, such as lauryl-CoA, palmitoyl-CoA and oleoyl-CoA, are potent inhibitors of ANT $[99,117]$. Two separate acyl-CoA binding sites on ANT from bovine heart have been suggested [99, 117, 118]. A clear correlation has also been demonstrated between the increase in intracellular acylCoA levels and the decrease in ANT activity in dog heart. ACBP greatly reduces the inhibition of mitochondrial ANT by LCFA in vitro (for review, see [33]).

Thus, the molecular mechanisms involved in LCFA catabolism and ATP production in cattle have been described in detail. However, further work is required to control the efficiency of ATP production from FA, so as to increase the energy available for muscle growth. 


\subsection{The importance of FA metabolism for muscle function}

The physiological functions of muscle are to: i) maintain the skeleton and allow movement; ii) facilitate thermogenesis at critical physiological stages such as birth; and iii) facilitate growth and therefore, meat production. These functions have different and competiting requirements for ATP. The link between the characteristics of muscle lipid metabolism and muscle functions has been reviewed in meat-producing animals [52].

It is well known that acute exercise leads to greater fat metabolism in all species due to the mobilisation of endogenous TG (for review, see [52]). Trained muscles also rely more heavily on fat as an energy source during exercise than do untrained muscles. For example, the development of solid food chewing in weaned calves leads concomitantly to: i) a very high level of almost constant physical activity of the masseter muscle in the cheek; and ii) an increase in oxidative enzyme activity (ICDH, LPL) in this muscle only $[50,87]$.

The stimulation of fat metabolism and heat production in muscles help animals to cope with adverse climatic conditions. Thus, extensive production systems (pasture grazing, with animals subjected to higher physical activity and variable climatic conditions) may lead to changes in muscle characteristics by increasing oxidative metabolism.

The accumulation of fat within the muscle tissues (mainly in intramuscular adipocytes) determines many qualities of the meat [36]. First, intramuscular fat content affects meat tenderness, although it accounts for less than $10 \%$ of the variation between samples [26]. Second, the 'juiciness' of the meat may be partly related to fat content [116]. Third, the flavour of meat is based largely on the quantity and chemical composition of muscle fat. Fat content is much higher in oxidative than in glycolytic muscles, and is higher in cattle than in pigs (1-6.3\% versus $0.7-3.7 \%$ of tissue wet weight). Fat content is also affected by age, breed, nutrition and animal management (for review, see [52]). The adipocytes responsible for the marbled appearance of meat use glucose or lactate as a substrate for lipogenesis much more than they use acetate [104]. This suggests that lipogenesis in intramuscular adipocytes could be manipulated with no increase in the fattiness of the carcass. This required more detailed knowledge of FA metabolism in intramuscular adipocytes. The ratio of PUFA to saturated FA in beef is approximately 0.11 , much lower than the recommended value $(0.45)$ [120]. Another challenge in ruminants is, therefore, to increase the ratio of polyunsaturated to saturated FA within the meat whilst retaining the desirable $n-6: n-3$ PUFA ratio found in the meat of grazing ruminants [120]. A suitable source of dietary vitamin $\mathrm{E}$ is also required to prevent oxidation of meat from ruminants. The oxidation of myoglobin to brown metmyoglobin is associated with the development of rancid odours and flavours caused by the degradation of PUFA in tissue membranes [120].

\section{EMERGING CONCEPTS IN THE REGULATION OF LIPID METABOLISM}

\subsection{Comparison of FA metabolism in rats and cattle}

It is well known that the rate of de novo FA synthesis in the bovine liver is only about $2 \%$ of that in rats [4]. More recent in vitro studies with liver slices have also shown that the rates of oleate incorporation, esterification and oxidation are 1.5-3.0 higher in rats than in calves. In both species, the oleate oxidation rate is on average $20 \%$ of the oleate incorporation rate. However, the rate of secretion of oleate in the TG of VLDL is about eight times lower in calves 
than in rats $[38,93]$. This is consistent with the low level of secretion of TG as VLDL in bovine liver. Similarly, hepatic TG production rates in sheep, pigs and dogs are much lower than those in rats or humans (for review, see [43]).

Other in vitro studies in our laboratory with fresh hepatic and cardiac homogenates have shown that the oxidation rates of palmitate in cattle is half that in rats, probably due to fewer mitochondria in bovine tissues. The relative contributions of peroxisomes to palmitate oxidation in the liver and the heart are, however, similar in rats and cattle under the same experimental conditions. In contrast, the relative contribution of peroxisomes to total palmitate oxidation is higher in bovine than in rat muscles (33\% versus $14 \%$, respectively [89]). CPT I activity is the rate-limiting step in FA oxidation. CPT proteins have been purified from calf liver [59] and bovine heart [34] in attempts to study the regulation of this step. But the CPT much studied in the older literature is the CPT II protein which is not rate-limiting. However, recent studies have shown that CPT I activity is higher in intermyofibrillar than in subsarcolemmal bovine muscle mitochondria, as in other species [88].

Thus, the major difference in FA metabolism between rats and ruminants is the very low ability of the ruminant liver to synthesise and secrete TG since other metabolic pathways in the liver or in muscles are sim ilar between these species. This may explain the high occurrence of fatty liver in cattle.

\subsection{Fate of MCFA in the liver of preruminant calves}

Replacing one third of the tallow of the milk replacer by coocunut oil (rich in C12:0 and $\mathrm{C14:0}$ ) increases protein retention in the preruminant calf (for review see [8]). More recent studies have shown that the TG content of the liver is 12 times higher with a milk-replacer with no tallow but rich in coconut oil than with a standard milk replacer rich in tallow [11]. C12:0 and C14:0, however, do not accumulate within the liver [11] although the fatty acid composition of circulating chylomicrons and VLDL is similar to that of the diet [29]. This may be explained by a modification of the oxidation process: C12:0 is more efficiently broken down, especially by the peroxisomes, than are LCFA in both rats [63] and calves [90]. They are broken down into short-chain FA, which can then be converted to LCFA and finally stored as TG [19]. In addition, the oxidation rate of specific FA, such as oleate, is lower with the coconut oil diet than with a typical milk-replacer [37]. This may result in oleate esterification and TG accumulation. Thus, coconut oil as only source of fat must not be recommended in milk-replacers for calves since it leads to an accumulation of fat in the liver.

\subsection{Regulation of FA metabolism by leptin}

Leptin is a recently discovered hormone secreted by mature adipocytes into the blood. Factors stimulating the secretion of leptin include food intake, body fat and insulin (for review, see [97]). Recent results in ewes show that leptin gene expression is also affected by photoperiod (for review, see [18]). Leptin inhibits food intake, reduces body weight, increases energy expenditure and seems to have a function in many tissues. For example, leptin directs LCFA towards oxidation rather than TG storage in rat muscles [76]. The TG contents of muscles, liver and adipose tissue are much lower in rats with high leptin levels than in control rats [102]. A restriction fragment length polymorphism has been identified in the PCR amplification products of the bovine leptin gene. The leptin gene maps to bovine chromosome 4 [91]. A clear aim of leptin research in livestock production would be to control food intake 
to increase the efficiency of production and to optimise body composition (for review, see [97]).

\subsection{Regulation of gene expression by LCFA via nuclear receptors}

Recent research, particularly in rodents, has shown that the expression of specific genes involved in the regulation of lipid metabolism are affected by nutrients, such as LCFA [78]. According to the 'overload hypothesis', a higher flux of LCFA to the liver stimulates a series of metabolic changes, ultimately resulting in activation of the peroxisome proliferator-activated receptors (PPARs). LCFA, which are poor substrates for $\beta$-oxidation, are much more potent PPAR activators than VFA, MCFA (C6-C10) and rapidly catabolised FA. PPARs form dimeric complexes with the 9-cis retinoic acid receptor (RXR). Activated receptors (PPARs/ RXR) increase or inhibit the expression of specific genes involved in the regulation of lipid metabolism. Generally, the expression of genes encoding enzymes involved in FA oxidation or KB production is increased, whereas the genes encoding enzymes involved in FA synthesis is decreased (for review, see [100]). The down-regulation of gene expression appears to be restricted to the liver and is exerted only by PUFA (for review, see [78]). Such molecular mechanisms have not yet been specifically demonstrated in bovines, but the possible involvement of PPAR activators should be considered because these molecules have a key role in the regulation of lipid metabolism. For example, phytol metabolites (especially phytanic acid) derived from chlorophyll are abundant in the plasma and tissue lipids of ruminants fed grass [67] and have been shown to activate RXR activators [57]. The expression of the liver-type FABP is, thus, transcriptionally enhanced by phytanic acid as shown in rodents [119]. Phytol metabolites are micro-nutrients that co-ordinate cellular mechanisms through RXR- dependent signalling pathways. The recent cloning of bovine PPARs [111] should provide further insight into the regulation of lipid metabolism by LCFA in bovine tissues.

\section{CONCLUSION}

It is clear that lipid metabolism in bovines is greatly influenced by characteristics of the digestive process. The regulation of the enzyme activities involved in the control of FA metabolism in the liver of growing and adult ruminants is less dependent on hormones and more dependent on VFA and their metabolites than that in the rat. However, dietary changes in the preruminant calf (curdled versus uncurdled proteins) or in ruminant cattle (forage versus concentratebased diets) may also significantly affect lipid metabolism by causing differences in the digestive processes. These effects may be linked to changes in hormone status or in nutrient supply.

Lipid metabolism may be regulated by nutrients via allosteric effects or enzyme regulation (inhibition of hepatic ketogenesis by propionate, of carbohydrate catabolism by fat catabolism, of fat catabolism by malonyl-CoA derived from lipogenesis and of oxidative phosphorylation by acyl-CoA esters). Nutrients may also have an effect by entering a specific metabolic pathway rather than any other. For example, lauric acid is much more efficiently broken down by hepatic peroxisomes than are LCFA. Nutrients may also act directly on gene expression, as demonstrated for glucose and LCFA in rodents. This area has not been investigated in cattle. Nevertheless, the effects of specific molecules derived from grass (e.g. phytol converted into phytanic acid by rumen bacteria) require further studies. The study of nuclear receptors in cattle is thus a key future objective of livestock science.

Some hepatic and muscular metabolic characteristics differ between single-stom- 
ached animals and ruminants. Thus, the high carnitine content of ovine and bovine muscles may help to buffer the high levels of acetate delivered to muscles in ruminants. In contrast, the low TG secretion capacity of the ruminant liver renders cattle susceptible to fatty liver in specific physiological stages (early lactation). It is also clear that glucose is the major carbon source for lipogenesis in intramuscular adipocytes rather than acetate as in other bovine fat deposits. The reason for this tissue specificity is unclear. The investigation of the molecular mechanisms regulating lipogenesis in intramuscular fat is probably one of the greatest challenges of the near future. It is becoming increasingly necessary to manipulate the fat content and fatty acid composition of muscle tissue to improve the quality and flavour of meat. The dietary qualities of muscle FA should also be improved.

Thus, newly acquired information (e.g. about nuclear receptors and leptin) should be combined with our knowledge about wellknown regulatory processes to provide new insight into lipid metabolism.

\section{ACKNOWLEDGMENTS}

The authors would like to thank Drs D. Durand, B. Graulet, D. Gruffat, I. OrtiguesMarty, C. Piot (Inra, laboratoire croissance et métabolismes des herbivores), Y. Chilliard (Inra, laboratoire sous-nutrition), P. Herpin (Inra, station de recherches porcines), Prof. D.W. Pethick (Murdoch University, Western Australia) and Prof. J.H. Veerkamp (University of Nijmegen, the Netherlands) for helpful advice and discussions.

\section{REFERENCES}

[1] Anthony G., Stroh A., Lottspeich F., Kadenbach B., Different isozymes of cytochrome-C oxidase are expressed in bovine smooth muscle and skeletal or heart muscle, FEBS Lett. 277 (1990) 97-100.

[2] Bach A.C., Ingenbleek Y., Frey A., The usefulness of dietary medium-chain triglycerides in body weight control: fact or fancy?, J. Lipid Res. 37 (1996) 708-726.
[3] Baird D.G., Ruminant ketosis, Bio. Soc. Trans 9 (1981) 348-349.

[4] Ballard F.J., Hanson R.W., Kronfeld D.S., Gluconeogenesis and lipogenesis in tissue from ruminant and non-ruminant animals, Fed. Proc. 28 (1969) 218-231.

[5] Bauchart D., Lipid absorption and transport in ruminants, J. Dairy Sci. 76 (1993) 3864-3881.

[6] Bauchart D., Aurousseau B., Digestion et métabolisme des lipides chez le veau de boucherie, conséquences sur la composition en lipides des tissus, Viandes Prod. Carnés 14 (1993) 172-182.

[7] Bauchart D., Aurousseau B., Auclair E., Addition of sorbitol to a milk substitute for veal calves. I. Effects on health, growth and feed conversion, Reprod. Nutr. Dev. 25 (1985) $411-425$.

[8] Bauchart D., Gruffat D., Durand D., Lipid absorption and hepatic metabolism in ruminants, Proc. Nutr. Soc. 55 (1996) 39-47.

[9] Bauchart D., Ortigues I., Hocquette J.F., Gruffat D., Durand D., Energy and fat metabolism of the liver, the digestive tract and muscles: transport, processing, energy consumption, fixation by tissues, in: The French Federation of Veal producers (Ed.), Veal, perspectives to the year 2000 , Proc. Int. Symp. Veal Production, 12-13 September 1995, Le Mans, France, 1996, pp. 255-290.

[10] Bauchart D., Gruffat D., Graulet B., Durand D., Production et stockage des triglycérides par le foie, Cah. Nutr. Diét. 32 (1997) 233-241.

[11] Bauchart D., Durand D., Picherit C., Graulet B., Gruffat D., Effets de l'huile de coprah sur le transport sanguin et le métabolisme hépatique in vivo des acides gras chez le veau préruminant, Nutr. Clin. Métabol. 11 (1997) 301.

[12] Blank S., Chen V., Ianuzzo C.D., Biochemical characteristics of mammalian diaphragms, Respir. Physiol. 74 (1988) 115-125.

[13] Brady P.S., Ramsay R.R., Brady L.J., Regulation of the long-chain carnitine acyltransferases, FASEB J. 7 (1993) 1039-1044.

[14] Brandstetter A.M., Picard B., Geay Y., Regional variations of muscle fibre characteristics in $\mathrm{m}$. semitendinosus of growing cattle, J. Muscle Res. Cell Motil. 18 (1997) 57-62.

[15] Brockman R.P., Glucose and short-chain fatty acid metabolism, in: Forbes J.M., France J. (Eds.), Quantitative Aspects of Ruminant Digestion and Metabolism, CAB International, Wallingford, Oxon, UK, 1993, pp. 249-264.

[16] Bruss M. L., Metabolic fatty liver of ruminants, Adv. Vet. Sci. Comp. Med. 37 (1993) 417-449

[17] Cadorniga-Valino C., Grummer R.R., Armentano L.E., Donkin S.S., Bertics S.J., Effects of fatty acids and hormones on fatty acid metabolism and gluconeogenesis in bovine hepatocytes, J. Dairy Sci. 80 (1997) 646-656.

[18] Chilliard Y., Bocquier F., Doreau M., Digestive and metabolic adaptations of ruminants to undernutrition, and consequences on reproduction, Reprod. Nutr. Dev. 38 (1998) 131-152. 
[19] Christensen E., Hagve T.A., Gronn M., Christophersen B.O., Beta-oxidation of medium chain (C8-C14) fatty acids studied in isolated liver cells, Biochim. Biophys. Acta (1989) 187-195.

[20] Clinquart A., Micol D., Brundseaux C., Dufrasne I., Istasse L., Utilisation des matières grasses chez les bovins à l'engraissement, Inra Prod. Anim. 8 (1995) 29-42.

[21] Cortright R.N., Muoio D.M., Dohm G.L., Skeletal muscle lipid metabolism: A frontier for new insights into fuel homeostasis, J. Nutr. Biochem. 8 (1997) 228-245.

[22] De Tata V., Fierabracci V., Gori Z., Bergamini E., Transmural distribution of glucose metabolizing enzymes across the left and the right ventricle heart walls in three different mammalian species, Comp. Biochem. Physiol. 84B (1986) 549-553.

[23] Doreau M, Chilliard Y., Digestion and metabolism of dietary fat in farm animals, Br. J. Nutr. 78 (1997) 515-535.

[24] Drackley J.K., Beitz D.C., Young J.W., Regulation of in vitro palmitate oxidation in liver from dairy cows during early lactation, J. Dairy Sci. 74 (1991) 1884-1892.

[25] Drackley J.K., Beitz D.C., Young J.W., Regulation of in vitro metabolism of palmitate by carnitine and propionate in liver from dairy cows, J. Dairy Sci. 74 (1991) 3014-3024.

[26] Dransfield E., Tenderness of meat, poultry and fish, in: Pearson A.M., Dutson T.R. (Eds.), Quality Attributes and their Measurement in Meat, Poultry and Fish Products, Blackie Academic and Professional, London, UK, 1994, pp. 289-315.

[27] Durand D., Bauchart D., Laplaud P.M., Lefaivre J., Chapman M.J., Importance of the portal venous pathway to the transport of intestinal triglyceride-rich lipoproteins in the preruminant calf, Reprod. Nutr. Dev. 30, suppl. 2 (1990) $228 \mathrm{~s}$.

[28] Durand D., Gruffat D., Chilliard Y., Bauchart D., Stéatose hépatique : mécanismes et traitements nutritionnels chez la vache laitière, Le Point Vétérinaire 27 (1995) 61-69.

[29] Durand D., Bauchart D., Picherit C., Gruffat D., Graulet B., Effets de l'huile de coprah sur la distribution et la composition des lipoprotéines plasmatiques chez le veau préruminant, Nutr. Clin. Métabol. 11 (1997) 301.

[30] Eaton S., Bartlett K., Pourfarzam M., Mammalian mitochondrial beta-oxidation, Biochem. J. 320 (1996) 345-357.

[31] Emery R.S., Liesman J.S., Herdt T.H., Metabolism of long-chain fatty acids by ruminant liver, J. Nutr. 122 (1992) 832-837.

[32] Edwards-Webb J.D., Thompson S.Y., Studies on lipid digestion in the preruminant calf. 2. A comparison of the products of lipolysis of milk fat by salivary and pancreatic lipases in vitro, Br. J. Nutr. 37 (1978) 431-440.
[33] Faergeman N.J., Knudsen J., Role of long-chain fatty acyl-coA esters in the regulation of metabolism and in cell signalling, Biochem. J. 323 (1997) 1-12.

[34] Fiol C.J., Bieber L.L., Sigmoid kinetics of purified beef heart mitochondrial carnitine palmitoyltransferase, J. Biol. Chem. 259 (1984) 13084-13088.

[35] France J., Siddons R.C., Volatile fatty acid production, in: Forbes J.M., France J. (Eds.), Quantitative Aspects of Ruminant Digestion and Metabolism, CAB International, Wallingford, Oxon, UK, 1993, pp. 107-120.

[36] German J.B., Muscle lipids, J. Muscle Foods 1 (1990) 339-361

[37] Graulet B., Gruffat D., Durand D., Bauchart D., Oxydation de l'oléate par des explants en survie issus de foie de veaux préruminants recevant un aliment lacté à base de suif ou d'huile de coprah, Nutr. Clin. Métabol. 11 (1997) 291.

[38] Graulet B., Gruffat D., Durand D., Bauchart D., Fatty acid metabolism in liver slices: a comparison between rat and preruminant calf, Frenchpolish Symposium on Nutrition and Animal Physiology, 23-24 June, 1998, Paris.

[39] Greeve J., Altkemper I., Dieterich J.H. Greten H., Windler E., Apolipoprotein mRNA editing in 12 different mammalian species: hepatic expression is reflected in low concentrations of apo B-containing plasma lipoproteins, J. Lipid Res. 34 (1993) 1367-1383.

[40] Grizard J., Toullec R., Guillauteau P., PatureauMirand $P$., Influence de la cinétique d'évacuation gastrique de l'aliment sur l'insulinémie chez le veau préruminant, Reprod. Nut. Dev. 22 (1982) 475-484.

[41] Gruffat D., Durand D., Graulet B., Bauchart D., Regulation of VLDL synthesis and secretion in the liver, Reprod. Nut. Dev. 36 (1996) 375-389.

[42] Gruffat D., Piot C., Durand D., Bauchart D., Developmental changes in apolipoprotein B gene expression in the liver of fetal calves, Biol. Neonate 74 (1998) 233-242.

[43] Grummer R.R., Ethiology of lipid-related metabolic disorders in periparturient dairy cows, J. Dairy Sci. 76 (1993) 3882-3896.

[44] Guilhermet R., Toullec R. Effect of the nature of nutrients on blood insulin in the ruminant calf, Reprod. Nutr. Dev. 23 (1983) 341-349.

[45] Guzman M., Geelen M.J.H., Regulation of fatty acid oxidation in mammalian liver, Biochim. Biophys. Acta 1167 (1993) 227-241.

[46] Hansford R.G., Control of mitochondrial substrate oxidation, Curr. Topics Bioeng. 10 (1980) 217-278.

[47] Harrison F.A., Leat W.M.F., Foster A., Absorption of maize oil infused into the duodenum of the sheep, Proc. Nutr. Soc. 33 (1974) 103. 
[48] Heitmann R.N., Dawes D.J., Sensenig S.C., Hepatic ketogenesis and peripheral ketone body utilization in the ruminant, J. Nutr. 117 (1987) 1174-1180.

[49] Henderson G.D., Xue G.P., Snoswell A.M., Carnitine and creatine content of tissues of normal and alloxan-diabetic sheep and rats, Comp. Biochem. Physiol. 76B (1983) 295-298.

[50] Hocquette J.F., Olivecrona T., Variations in lipoprotein lipase activity in muscle and adipose tissues between preruminant and weaned calves, Ann. Zootech. 44 (suppl.) (1995) 294.

[51] Hocquette J.F., Graulet B., Olivecrona T., Lipoprotein lipase activity and gene expression in bovine tissues, Comp. Biochem. Physiol. 121B (1998) 201-212.

[52] Hocquette J.F., Ortigues-Marty I., Pethick D., Herpin P., Fernandez X., Nutritional and hormonal regulation of energy metabolism in skeletal muscles of meat-producing animals, Livest. Prod. Sci. 56 (1998) 115-143.

[53] Inra, Alimentation des ruminants, Inra Pub., Versailles, France, 1978.

[54] Jenkins T.C., Lipid metabolism in the rumen, J. Dairy Sci. 76 (1993) 3851-3863.

[55] Jesse B.W., Emery R.S., Thomas J.W., Control of bovine hepatic fatty acid oxidation, J. Dairy Sci. 69 (1986) 2290-2297.

[56] Jesse B.W., Emery R.S., Thomas J.W., Aspects of the regulation of long-chain fatty acid oxidation in bovine liver, J. Dairy Sci. 69 (1986) 2298-2303.

[57] Kitareewan S., Burka L.T., Tomer K.B., Parker C.E., Deterding L.J., Stevens R.D., Forman B.M., Mais D.E., Heyman R.A., McMorris T., Weinberger C., Phytol metabolites are circulating dietary factors that activate the nuclear receptor RXR, Mol. Biol. Cell 7 (1996) 1153-1 166.

[58] Kobayashi A., Jiang L.L., Hashimoto T., Two mitochondrial 3-hydroxyacyl-CoA dehydrogenases in bovine liver, J. Biochem. 119 (1996) 775-782.

[59] Kopeck B., Fritz I., Properties of a purified carnitine palmitoyltransferase, and evidence for the existence of other carnitine acyltransferases, Can. J. Biochem. 49 (1971) 941-950.

[60] Lai J.C.K., Rimpel-Lamhaouar K. Cooper A.J.L., Differential inhibition of mitochondrial dehydrogenases by fatty acyl-CoAs, Ann. NY Acad. Sci. 573 (1989) 420-422.

[61] Laplaud P.M., Bauchart D., Durand D., Chapman M.J., Lipoproteins and apolipoproteins in intestinal lymph of the preruminant calf, Bos spp., at peak lipid absorption, J. Lipid Res. 31 (1990) 1781-1792.

[62] Laplaud P.M., Bauchart D., Durand D., Beaubatie L., Chapman M.J., Intestinal lymph and plasma lipoproteins in the preruminant calf: partial resolution of particle heterogeneity in the $1.040-1.090 \mathrm{~g} / \mathrm{mL}$ interval, J. Lipid Res. 32 (1991) 1429-1439.
[63] Leighton F., Persico R., Necochea C., Peroxisomal fatty acid oxidation is selectively inhibited by phenothiazines in isolated hepatocytes, Biochem. Biophys. Res. Comm. 120 (1984) 505-511.

[64] Leplaix-Charlat L., Durand D., Bauchart D., Effects of diets containing tallow and soybean oil with and without cholesterol on hepatic metabolism of lipids and lipoproteins in the preruminant calf, J. Dairy Sci. 79 (1996) 1826-1835.

[65] Leplaix-Charlat L., Bauchart D., Durand D., Laplaud P.M., Chapman M.J., Plasma lipoproteins in preruminant calves fed diets containing tallow or soybean oil with and without cholesterol, J. Dairy Sci. 79 (1996) 1267-1277.

[66] Lopaschuk G.D., Belke D.D., Gamble J., Itoi T., Schonekess B.O., Regulation of fatty acid oxidation in the mammalian heart in health and disease, Biochim. Biophys. Acta 1213 (1994) 263-276.

[67] Lough A.K., The phytanic acid content of the lipids of bovine tissues and milk, Lipids 12 (1977) 115-119.

[68] Lowe M., Tubbs P.K., Succinylation and inactivation of 3-hydroxy-3-methylglutaryl-CoA synthase by succinyl-CoA and its possible relevance to the control of ketogenesis, Biochem. J. 232 (1985) 37-42.

[69] Malki M.C., Kante A., Demigne C., Latruffe N., Expression of R-3-hydroxybutyrate dehydrogenase, a ketone body converting enzyme in heart and liver mitochondria of ruminant and non-ruminant mammals, Comp. Biochem. Physiol. 101B (1992) 413-420.

[70] McGarry J.D., Brown N.F., The mitochondrial carnitine palmitoyltransferase system from concept to molecular analysis, Eur. J. Biochem. 244 (1997) 1-14.

[71] McGarry J.D., Mills S.E., Long S.L., Foster D.W., Observations on the affinity for carnitine, and malonyl-coA sensitivity, of carnitine palmitoyltransferase I in animal and human tissues. Demonstration of the presence of malonyl-coA in non-hepatic tissues of the rat, Biochem. J. 214 (1983) 21-28.

[72] Merle P., Kadenbach B., Kinetic and structural differences between cytochrome $c$ oxidases from beef liver and heart, Eur. J. Biochem 125 (1982) 239-244.

[73] Meunier-Durmort C., Poirier H., Niot I., Forest C., Besnard P., Up-regulation of the expression of the gene for liver fatty acid-binding protein by long-chain fatty acids, Biochem. J. 319 (1996) $483-487$.

[74] Mikkelsen J., Hojrup P., Nielsen F., Roepstorff P., Knudsen J., Amino acid sequence of acyl-CoAbinding protein from cow liver, Biochem. J. 245 (1987) 857-861.

[75] Moore K.K., Ereken P.A., Lunt D.K., Smith S.B., Relationship between fatty acid-binding protein activity and marbling scores in bovine longissimus muscle, J. Anim. Sci. 69 (1991) 1515-1521. 
[76] Muoio D.M., Dohm G.L., Fiedorek F.T., Tapscott E.B., Coleman, Leptin directly alters lipid partitioning in skeletal muscle, Diabetes 46 (1997) 1360-1363.

[77] Nelson J.M., Campion D.R., Reagan J.O., Postmortem loss of carnitine from skeletal muscle of pork and beef, J. Food Sci. 50 (1985) 1183-1184.

[78] Niot I., Poirier H., Besnard P., Regulation of gene expression by fatty acids: special reference to fatty acid-binding protein (FABP), Biochimie 79 (1997) 129-133.

[79] Nishina P.M., Freedland R.A., Effects of propionate on lipid biosynthesis in isolated rat hepatocytes, J. Nutr. 120 (1990) 668-673.

[80] Noble R.C., Lipid metabolism in the neonatal ruminant, Prog. Lipid Res. 18 (1980) 179-216.

[81] Palmquist D.L., Jenkins T.C., Fat in lactation rations, J. Dairy Sci. 63 (1980) 1-14.

[82] Pethick D.W., Energy metabolism of skeletal muscle, in: Gawthorne J.M., Baker S.K., Mackintosh J.B., Purser D.B. (Eds.), Ruminant Physiology, Concepts and consequences, 1984, Symposium held at University of Western Australia, 7-10 May 1984, Nedlands, Australia, 1984, pp. 277-287.

[83] Pethick D.W., Lindsay D.B., Metabolism of ketone bodies in pregnant sheep, Br. J. Nut. 48 (1982) 549-563.

[84] Pethick D.W., Dunshea F.R., Fat metabolism and turnover, in: Forbes J.M., France J. (Eds.), Quantitative Aspects of Ruminant Digestion and Metabolism, CAB International, Wallingford, Oxon, UK, 1993, pp. 291-311.

[85] Pethick D.W., Lindsay D.B., Barker P.J., Northrop A.J., Acetate supply and utilization by the tissues of sheep in vivo, Br. J. Nut. 46 (1981) 97-111.

[86] Pethick D.W., Lindsay D.B., Barker P.J., Northrop A.J., The metabolism of circulating non-esterified fatty acids by the whole animal, hind-limb muscle and uterus of pregnant ewes, Br. J. Nutr. 49 (1983) 129.

[87] Picard B., Gagnière H., Geay Y., Contractile differentiation of bovine masseter muscle, BAM 5 (1996) 361-372.

[88] Piot C., Hocquette J.F., Herpin P., Durand D., Bauchart D., CPT I activity in calf muscles: effects of fatty acids. Proc. Annual Congress GERLI, Dijon, France, 1997.

[89] Piot C., Veerkamp J.H., Bauchart D., Hocquette J.F., Contribution of mitochondria and peroxisomes to palmitate oxidation in rat and bovine tissues, Comp. Biochem. Physiol. 121B (1998) 185-194.

[90] Piot C., Veerkamp J.H., Bauchart D., Hocquette J.F., Contribution of peroxisomes to fatty acid oxidation in tissues from preruminant calves: effects of the nature of dietary fatty acids. $3^{5}$ British-French-Meeting on Nutrition, Nancy, September, 1998.
[91] Pomp D., Zou T., Clutter A.C., Barendse W., Rapid communication: mapping of leptin to bovine chromosome 4 by linkage analysis of a PCR-based polymorphism, J. Anim. Sci. 75 (1997) 1427.

[92] Prip-Buus C., Thumelin S., Chatelain F., Pégorier J.P., Girard J., Hormonal and nutritional control of liver fatty acid oxidation and ketogenesis during development, Biochem. Soc. Trans. 23 (1995) 500-506.

[93] Pullen D.L., Liesman J.S., Emery R.S., A species comparison of liver slice synthesis and secretion of triacylglycerol from non-esterified fatty acids in media, J. Anim. Sci. 68 (1990) 1395-1399.

[94] Ramsay R.R., The soluble carnitine palmitoyltransferase from bovine liver: a comparison with the enzymes from peroxisomes and from the mitochondrial inner membrane, Biochem. J. 249 (1988) 239-245.

[95] Ricks C.A., Cook R.M., Regulation of volatile fatty acid uptake by mitochondrial acyl-CoA synthetases of bovine liver, J. Dairy Sci. 64 (1981) 2324-2335.

[96] Rolfe D.F.S., Brand, M.D., The physiological significance of mitochondrial proton leak in animal cells and tissues, Biosci. Rep. 17 (1997) 9-16.

[97] Romsos D.R., Opportunities for application of studies on leptin in animal production, in: McCracken K., Unsworth E.F., Wylie A.R.G. (Eds.), Energy Metabolism of Farm Animals, CAB International, 1998, pp. 1-12.

[98] Rottenberg H., Decoupling of oxidative phosphorylation and photophosphorylation, Biochim. Biophys. Acta 1018 (1990) 1-17.

[99] Ruoho A.E., Woldegiorgis G., Kobayashi C., Shrago E., Specific labeling of beef heart mitochondrial ADP/ATP carrier with N-(3-Iiodo4-azidophenylpropionamido) cysteinyl-5-(2'synthesised ${ }^{125}$ I-Coenzyme A) derivative photolabel, J. Biol. Chem. 264 (1989) 4168-4172.

[100] Schoonjans K., Staels B., Auwerx, Role of the peroxisome proliferator-activated receptor (PPAR) in mediating the effects of fibrates and fatty acids on gene expression, J. Lipid Res. 37 (1996) 907-925.

[101] Shaw L., Engel P.C., The suicide inactivation of ox liver short-chain acyl-coA dehydrogenase by propionyl-CoA, Biochem. J. 230 (1985) 723-731.

[102] Shimabukuro M., Koyama K., Chen G., Wang MY, Trieu F., Lee Y., Newgard C.B., Unger R.H., Direct antidiabetic effect of leptin through triglyceride depletion of tissues, Proc. Natl. Acad. Sci. USA 94 (1997) 4637-4641.

[103] Small C.A., Garton A.J., Yeaman S.J., The presence and role of hormone-sensitive lipase in heart muscle, Biochem. J. 258 (1989) 67-72. 
[104] Smith S.B., Crouse J.D., Relative contributions of acetate, lactate and glucose to lipogenesis in bovine intramuscular and subcutaneous adipose tissue, J. Nutr. 114 (1984) 792-800.

[105] Smith S.B., Ereken P.A., Sanders J.O., Fatty acid-binding protein activities in bovine mucle, liver and adipose tissue, J. Nutr. 115 (1985) 1535-1539.

[106] Snoswell A.M., Henderson G.D., Carnitine and metabolism in ruminant animals, in: Frenkel R.A., McGarry J.D. (Eds.), Carnitine Biosynthesis, Metabolism and Functions, 1980, pp. 191-205.

[107] Soboll, Regulation of energy metabolism in liver, J. Bioenerg. Biomembr. 27 (1995) 571-582.

[108] Souid A.K, Penefsky H.S., Mechanism of ATP synthesis by mitochondrial ATP synthase from beef heart, J. Bioenerg. Biomembr. 26 (1994) $627-630$

[109] Spurway N.C., Murray M.G., Gilmour W.H., Montgomery I., Quantitative skeletal muscle histochemistry of four east african ruminants, J. Anat. 188 (1996) 455-472.

[110] Strang B.D., Bertics S.J., Grummer R.R., Armentano L.E., Relationship of triglyceride accumulation to insulin clearance and hormonal responsivness in bovine hepatocytes, J. Dairy Sci. 81 (1998) 740-747.

[111] Sundvold H., Brzozowska A., Lien S., Characterisation of bovine peroxisome proliferatoractivated receptors gamma $\mathbf{I}$ and gamma 2 : genetic mapping and differential expression of the two isoforms, Biochem. Biophys. Res. Commun. 239 (1997) 857-861.

[112] Toullec R., Guilloteau P., Coroller J.Y., Influence de la cinétique d'évacuation gastrique de l'aliment sur l'absorption chez le veau préruminant, Ann. Biol. Anim. Biochim. Biophys. 19 (1979) 729-732.
[113] Vamecq J., Draye J.P., Pathophysiology of peroxisomal beta oxidation, Essays Biochem. 24 (1989) 115-225.

[114] van Houtert M.F.J., The production and metabolism of volatile fatty acids by ruminants fed roughages: A review, Anim. Feed Sci. Technol. 43 (1993) 189-225.

[115] Veerkamp J.H., Fatty acid transport and fatty acid-binding proteins, Proc. Nutr. Soc. 54 (1995) 23-37.

[116] Winger R.J., Hagyard C.J., Juiciness - its importance and some contributing factors, in: Pearson A.M., Dutson T.R. (Eds.), Quality Attributes and their Measurement in Meat, Poultry and Fish Products, Blackie Academic and Professional, London, UK, 1994, pp. 289-315.

[117] Woldegiorgis G., Shrago E., Gipp J., Yatvin M., Fatty acyl coenzyme A-sensitive adenine nucleotide transport in a reconstituted liposome system, J. Biol. Chem. 256 (1981) 12297-12300.

[118] Woldegiorgis G., Yousufzai S.Y.K., Shrago E., Studies on the interaction of palmitoyl coenzyme A with the adenine nucleotide translocase, J. Biol. Chem. 257 (1982) 14783-14787.

[119] Wolfrum C., Phytanic acid, a transcriptional activator is ligand for liver-type fatty acid binding protein and PPAR $\alpha, 8$ th FABP mini-workshop, 15 January, 1998, Nijmegen.

[120] Wood JD, Enser M.; Factors influencing fatty acids in meat and the role of antioxidants in improving meat quality, Br. J. Nutr. (suppl. 1) (1997) S49-S60.

[121] Zammit V.A., Ketogenesis in the liver of ruminants-adaptations to a challenge, J. Agric. Sci. 115 (1990) 155-162.

[122] Zammit V.A., Role of insulin in hepatic fatty acid partitioning: emerging concepts, Biochem. J. 314 (1996) 1-14. 